\title{
A decade of sulfite control in Serbian meat industry and the effect of HACCP
}

\section{Igor Tomasevic, Margarita Dodevska, Milan Simić, Smiljana Raicevic, Violeta} Matovic \& Ilija Djekic

To cite this article: Igor Tomasevic, Margarita Dodevska, Milan Simić, Smiljana Raicevic, Violeta Matovic \& Ilija Djekic (2017): A decade of sulfite control in Serbian meat industry and the effect of HACCP, Food Additives \& Contaminants: Part B, DOI: 10.1080/19393210.2017.1403492

To link to this article: http://dx.doi.org/10.1080/19393210.2017.1403492

Accepted author version posted online: 16

Nov 2017.

Submit your article to this journal $[\pi$

Q View related articles $₫$

View Crossmark data \ulcorner 


\title{
A decade of sulfite control in Serbian meat industry and the effect of HACCP
}

Igor Tomasevic ${ }^{\mathrm{a}}{ }^{*}$, Margarita Dodevska ${ }^{\mathrm{b}}$, Milan Simić $^{\mathrm{b}}$, Smiljana Raicevic ${ }^{\mathrm{b}}$, Violeta Matovic $^{\mathrm{b}}$, Ilija Djekic ${ }^{\mathrm{c}}$

${ }^{\text {a }}$ Department of Animal Source Food Technology, University of Belgrade, Faculty of Agriculture, Nemanjina 6, 11080 Belgrade, Republic of Serbia

${ }^{\mathrm{b}}$ Center for Food Analysis, Zmaja od Nocaja 11, 11000 Belgrade, Republic of Serbia

${ }^{c}$ Food Safety and Quality Management Department, University of Belgrade, Faculty of Agriculture, Nemanjina 6, 11080 Belgrade, Republic of Serbia

Corresponding author: Igor Tomasevic, Email: tbigor@agrif.bg.ac.rs

\begin{abstract}
In total 7,351 meat preparations and fresh processed meat products were analyzed from 555 different Serbian meat producers over a 10 year period, $4 \frac{1}{2}$ years before and $5 \frac{1}{2}$ years after mandatory HACCP implementation. From the obtained results, it could be concluded that HACCP has contributed to a better alignment of practices with the legal provisions. The share of non-compliant samples dropped from $18.6 \%$ before HACCP to $8.3 \%$ after its mandatory implementation. Average sulfite concentrations for all categories of meat preparations and fresh processed meat products decreased by $43 \%$, declining from $33.6 \mathrm{mg} \mathrm{kg}-1$ to $19.3 \mathrm{mg} \mathrm{kg}-1$. Typical misuse and frequent abuse of sulfites was independent of a season. Application of HACCP principles in the Serbian meat industry raised awareness about the misuse of sulfites and contributed to a better control, minimizing exposure to sulfites.
\end{abstract}

Keywords: Sulfite; Meat preparations, Meat products; HACCP; Serbia.

\section{Introduction}

Sulfur dioxide and sulfites comprise the group of compounds known collectively as sulfites. The major purpose of sulfites in raw meat products is credited to their antimicrobial activity (Ruiter and Scherpenisse 2011), which allows prolongation of the shelf life of these products kept in cooling environment. Even a small amount of sulfite in meat imparts a bright red color due to its antioxidant activity. Sulfites are used because they improve food appearance by controlling enzymatic and non-enzymatic browning reactions occurring from the Maillard-type reactions (Ruiz-Capillas and Jiménez-Colmenero 2009).

The concentration in different foods is expressed as sulfur dioxide $\left(\mathrm{SO}_{2}\right)$ in $\mathrm{mg} \mathrm{kg}-1$ or $\mathrm{mg} / \mathrm{l}$ depending on the nature of the food and is related to the total quantity from all sources. The European legislation approves the addition of sulfites to burger meat with a minimum content of cereals and/or vegetables of $4 \%$, breakfast sausages, and two types of traditional Spanish raw sausages, at maximum levels of $450 \mathrm{mg}$ of total $\mathrm{SO}_{2} / \mathrm{kg}$. The same legislation also declares that a 
$\mathrm{SO}_{2}$ content of no more than $10 \mathrm{mg} \mathrm{kg}-1$ or $10 \mathrm{mg} / 1$ is considered not to be present (European Commission, 2011). However, in other countries sulfur dioxide is prohibited in these kinds of foods. Thus, in the United States, foods recognized as a source of vitamin B1 (red meat) must be free of sulfites.

Sulfiting agents have also been included in the allergens list (European Commission, 2003) making it mandatory to indicate on the label of any food containing concentrations higher than $10 \mathrm{mg} \mathrm{kg}-1$ (expressed as $\mathrm{SO}_{2}$ ), for the benefit of people with a food intolerance for sulfite (European Commission, 2000). An acceptable daily intake (ADI) for sulfite is $0.7 \mathrm{mg} \mathrm{kg}-1$ of body weight and it is considered especially important that $\mathrm{SO}_{2}$ must be minimized in food with high thiamine content, such as red meat (FAO/WHO, 1986).

In the Republic of Serbia, Hazard Analysis and Critical Control Points (HACCP) was firstly introduced by virtue of the Veterinary Law (Serbia, 2005). Its mandatory implementation, for all animal source food producers, became effective only in June $1^{\text {st }}$ of 2011 after the adoption of a new Food Safety Law (Serbia, 2009). By the end of 2012, almost all Serbian meat producers (93.5\%) had an operational and certified HACCP system in place (Tomašević et al. 2013).

Throughout the western Balkan region, ground meat is raised to a form of art. Pljeskavica (plyess-ka-vee-tsa) is made from ground meat and minced onion, pounded thin, shaped like a burger and then grilled on both sides to a smoky brown product. The word "pljeskavica" comes from "pljesak", a regional word for clapping the hands, the motion used to press the burger into a thin round. With "ćevapi" (chay-vop-ee) the meat is shaped into cylinders to make it hold together well. They are formed by hand or extruded through a funnel. Both meat products are grilled over very high heat to lightly char the outside on all sides to a smoky brown and keep the inside juicy.

European and current Serbian legislation do not approve the addition of sulfites to "pljeskavica" or "ćevapi". In recognition of the significance of minced meat in the Serbian diet, the Directorate for Veterinary Affairs has never approved the addition of sulfur dioxide to minced meat sold in Serbia. Therefore, any addition of sulfites to meat preparations and fresh processed meat products (except for burger meat with a minimum content of cereals and/or vegetables of $4 \%$ ) in Serbia is deemed illegal.

This survey was conducted to assess meat preparations and fresh processed meat products for $\mathrm{SO}_{2}$ content by sampling meat producers of all sizes in geographically diverse areas of the Republic of Serbia. It was intended to obtain a representative sample of meat preparations and fresh processed meat products and to determine if changes in $\mathrm{SO}_{2}$ concentrations had occurred in the last decade. The main objective of this study was to establish if the mandatory HACCP implementation had had an impact on misuse and control of sulfites in the Serbian meat industry. Another objective was to identify the type of meat product contributing most to the total intake of sulfites. The acquired data will also be useful for future assessments of dietary exposure of sulfites for Serbia consumers. 


\section{Materials and Methods}

Meat product samples

All samples $(7,351)$ were procured from retailers by the Center for Food Analysis (CFA), Belgrade, Serbia, and were manufactured by 555 different meat producers located throughout the country. After collection the samples were stored at $4{ }^{\circ} \mathrm{C}$ and transported by road in dry ice packs to the CFA laboratory for analysis. All samples were analyzed within 3 days of procurement. Meat producers involved were of all sizes, with an estimated $70 \%$ share of the Serbian meat preparations and fresh processed meat products market. Ten years (2007 to 2016) were encompassed by this investigation, divided into two periods: the first was from January 1 st 2007 until May 31st 2011 (2,929 samples from a period of $4 \frac{1}{2}$ years before mandatory HACCP implementation) and the second from June 1st 2011 until December 31st 2016 (4,422 samples from a period of $51 / 2$ years after HACCP became mandatory). All samples, with an average size of $400 \mathrm{~g}$, were homogenized and analyzed using the enzymatic method according to the ISO procedure for determination of sulfite in foodstuffs (ISO 1988-2:1998).

Statistical analysis

All results represented the mean value of 3 replicates for each sample. Data were analyzed using SPSS Statistics 17.0 (Chicago, Illinois, USA) data analysis software. Factorial analysis of variance (ANOVA) and post hoc Tuckey analysis of Honestly Significant Difference (HSD) were used. The level of statistical significance was set at 0.05 .

\section{Results and Discussion}

The analytical method was validated by determining the limit of detection (LOD), the limit of quantification (LOQ), the relative standard deviation calculated under repeatability conditions $\left(\mathrm{RSD}_{\mathrm{r}}\right)$ and the relative standard deviation calculated under reproducibility conditions $\left(\mathrm{RSD}_{\mathrm{R}}\right)$, according to the European procedure for screening methods (European Commission, 2002). LOD was calculated by the equation LOD $=\mathrm{X}_{\text {blank }}+3 \mathrm{x} \mathrm{SD}_{\text {blank }}$ and $\mathrm{LOQ}=\mathrm{X}_{\text {blank }}+10 \mathrm{x} \mathrm{SD}_{\text {blank}}$; where $\mathrm{X}_{\text {blank }}$ is the mean concentration of the blank and $\mathrm{SD}_{\text {blank }}$ is the standard deviation of the blank. The LOD was $3.8 \mathrm{mg} \mathrm{kg}-1$; the LOQ was $9.0 \mathrm{mg} \mathrm{kg}-1$; $\mathrm{RSD}_{\mathrm{r}}$ was $4.9 \%$, $\mathrm{RSD}_{\mathrm{R}}$ was $3.7 \%$ and the mean recovery was $96 \%$. The analytical laboratory participated in the FAPAS ${ }^{\odot}$ (Food Analysis Performance Assessment Scheme) proficiency testing program, with the latest sulphur dioxide in meat sample test conducted in 2016 (asigned value $491 \mathrm{mg} \mathrm{kg}^{-1}$; range for $|z|<2$ was $430-553 \mathrm{mg} \mathrm{kg}^{-1}$, recording a $z$-score of 1.9 , indicating satisfactory analytical performance; FAPAS 2016).

According to this study the illegal addition of sulfur dioxide to meat preparations and fresh processed meat products in Serbian meat industry is a fact, at least in the last ten years. In the period 2007 to 2016, of 7,351 samples 911 (12.4\%) contained sulfur dioxide. The number of non-compliant samples ranged from $23.3 \%$ in 2007 to a $7 \%$ in 2016 (Table 1). Over a decade the most affected were ćevapi (15.7\%) and minced pork (14.7\%), followed by pljeskavica (10.4\%), minced beef $(10.1 \%)$ and fresh sausages $(8.9 \%)$. The seriousness of the situation is perhaps best described by the following example. In the 2010 survey, 193 samples of ćevapi were analyzed. Of these, 60 samples (31\%) contained sulfur dioxide (Table 1). However, the big share of positive samples discovered in this study is still smaller then percentage for presence of sulfites reported for Spain. There it was previously reported that $65.38 \%$ of beef and pork burgers (Zubeldia Lauzurica and Gomar Fayos 1997), 62.5\% of the uncooked burgers (Armentia 
Alvarez et al. 1993) and 62\% of the sausages analyzed (Paíno-Campa et al. 1991) contained levels of total $\mathrm{SO}_{2}$ above $450 \mathrm{mg} \mathrm{kg}-1$. Most recent results reported for Spain state that $18 \%$ of meat samples exceeded the maximum level of total sulfite (Pena-Egido et al. 2005), very similar to the results observed in this study in a period before mandatory HACCP implementation where $18.6 \%$ of the samples were found to be non-compliant (Table 2).

The presented investigations also revealed that in the last 10 years the highest average level of sulfur dioxide $43.6 \pm 83.8 \mathrm{mg} \mathrm{kg}-1 \quad(\mathrm{n}=458)$ was observed in 2007 , which is not significantly different from the ones observed in 2009 and 2010 (Table 1). It was considered highly unlikely that the addition of sulfur dioxide is due to lack of knowledge within the meat industry. It must be concluded that by adopting this practice, a significant number of Serbian meat traders deliberately violates the law and risk prosecution before mandatory implementation of HACCP.

A recent study of the Serbian meat industry reported that $93.5 \%$ of the producers surveyed, claimed they had a fully operational and certified HACCP system in place, whilst the remaining $6.5 \%$ had a HACCP system in place which was not certified (Tomašević et al. 2013). Strong affirmative effect of mandatory HACCP implementation on process hygiene indicators in Serbian meat facilities was already confirmed (Tomasevic et al. 2016). However, the smaller enterprises are reported to experience problems in introducing such HACCP based systems, due to factors such as awareness of the legislation and requirements, cost of implementation, availability of systems and training (Djekic et al.2011, Tomašević et al. 2013).

Current research revealed that average sulfur dioxide concentrations in all investigated categories of Serbian meat products reduced by $43 \%$ since meat producers report the levels of additives used and provide documentation with the amounts and concentrations of additives purchased/used in a specified production period, as obligatory due to the implemented HACCP legislation. The average sulfite concentrations significantly decreased from $33.6 \pm 73.8 \mathrm{mg} \mathrm{kg}-1$ $(n=2,929)$ before, to $19.3 \pm 63.1 \mathrm{mg} \mathrm{kg}-1 \quad(n=4,422)$ after the period of mandatory HACCP implementation. It was also discovered that mandatory HACCP implementation has contributed to a better alignment of practices with the legal provisions, since the percentage of noncompliant samples dropped from $18.6 \%$ (15-870 mg kg-1) to $8.3 \%$ (11-898 $\mathrm{mg} \mathrm{kg}-1$ ) (Table 2). The current situation in Serbia is obviously quite similar to the one observed in Italy during the last 3 years, where $6.4 \%$ of meat product samples were positive at a sulfur dioxide screening test and $2.8 \%$ of these samples showed sulfite concentrations in the range $67.6-1437 \mathrm{mg} \mathrm{kg}-1$ (Iammarino et al. 2017). Slightly lower data were reported for Hong Kong where $4.7 \%$ of the meat product samples contained sulfur dioxide at levels between 23 and 3,300 mg kg-1 (Chan, 2007).

The minimum share of non-compliant samples after the mandatory HACCP implementation was observed in minced beef $(2.5 \%)$, followed by fresh sausages $(5.4 \%)$, pljeskavica $(5.9 \%)$ and ćevapi $(10.6 \%)$. The least positively affected group of meat products investigated was minced pork although the average sulfite concentrations significantly decreased from $30.2 \pm 69.7 \mathrm{mg} \mathrm{kg}-1$ $(\mathrm{n}=344)$ to $22.8 \pm 58.9 \mathrm{mg} \mathrm{kg}-1 \quad(\mathrm{n}=315)$. The share of non-compliant minced pork samples dropped only by $1.3 \%$ with the introduction of mandatory HACCP implementation (Table 2). The use of sulfur dioxide in minced pork continues to be an issue in Serbia, contrary to the situation reported for example in Scotland. There, only $2 \%$ of samples contained this 
preservative in a period of 2000-2002 (Mackie 2005) while no Scottish chain retailers sold minced pork containing sulfur dioxide in recent years (Bradley 2013).

Of 1,689 samples analyzed in this study for sulfites in summer, $14.1 \%$ were assessed as noncompliant. Almost the same condition was observed in winter where $13.8 \%$ of 2,033 samples were found positive for the presence of sulfur dioxide (Table 3). This it seems that typical misuse and frequent abuse of sulfites in Serbian meat industry is independent of the season. Average sulfite concentrations observed in spring $21.5 \pm 59.4 \mathrm{mg} \mathrm{kg}-1 \quad(\mathrm{n}=2,288)$, summer $25.8 \pm 68.4 \mathrm{mg}$ $\mathrm{kg}-1(\mathrm{n}=1,689)$ and autumn $24.9 \pm 74.2 \mathrm{mg} \mathrm{kg}-1$ were not found to be significantly different (Table 3).

Despite the obviously positive influence of the introduction of HACCP in Serbian meat industry to control use of sulfites, the actual situation on the Serbian market is still far away from the conclusion that sulfites should be given the lowest weight as chemical hazards as it was the case in Belgium (Baert et al., 2011). For the Belgian market this conclusion could only be drawn after a study of Vandevijvere et al. (2010), who showed that sulfites intake was below the ADI in Belgium. To achieve this optimal situation in Serbia veterinary inspectors should increase the frequency of official controls for the presence of sulfur dioxide in meat and meat products, identify ways of eliminating illegal practices and prosecute violators of Food Law regulations, as to stop misuse and potential unhealthy effects of this practice for consumers.

\section{Conclusions}

Although it is obvious that HACCP raised awareness among Serbian meat producers about the misuse and control of sulfites, the results of this study show that the actual situation on the Serbian market is far from ideal. Therefore the Ministry of Agriculture and the Serbian Directorate for Veterinary Affairs can find enough reasons to engage with the meat industry to highlight this continuing problem. As long as this situation does not improve, authorities have enough reason to continue to enforce food safety regulations and prosecute businesses that illegally add sulfites to meat preparations and fresh processed meat products.

\section{References}

Baert K, Van Huffel X, Wilmart O, Jacxsens L, Berkvens D, Diricks H, Huyghebaert A, Uyttendaele M. 2011. Measuring the safety of the food chain in Belgium: Development of a barometer. Food Research International. 44:940-950.

Bradley P. 2013. A Report by the Scottish Food Enforcement Liaison Committee's Sampling and Surveillance Working Group. Edinburgh.

Chan, M. 2007. Sulphur Dioxide in Meat. Food Safety Focus(17), 2.

Djekic I, Tomasevic I, Radovanovic R. 2011. Quality and food safety issues revealed in certified food companies in three Western Balkans countries. Food Control. 22:1736-1741.

European Commision 2011. Commission Regulation 1129/2011 of 11 November 2011 amending Annex II to Regulation (EC) No 1333/2008 of the European Parliament and of the Council by establishing a Union list of food additives. Official Journal of the European Union, L295, 1-177. 
European Commission 2000. Directive (EC) No. 13/2000 (2000, Mar. 20). Office of the Journal of the European Union, L109, 29-42.

European Commision 2002. Commission Regulation 2002/657/EC of 14 August 2002 implementing council directive 96/23/EC concerning the performance of analytical methods and the interpretation of results. Official Journal of the European Union, L221, 8-36.

European Commission 2003. Directive (EC) No. 89/2003 (2003, Nov. 10). Office of the Journal of the European Union, L308, 15-18.

FAPAS 2016. Food Analysis Performance Assessment Scheme. Proficiency Testing Report 20126, April-May 2016, The Food and Environment Research Agency, Sand Hutton, York YO41 1LZ, UK.

FAO/WHO Food and Agriculture Organization/World Health Organization 1986. Evaluation of certain additive and polluting agents in foods. 291 Report of Mixed Committee FAO/WHO of Food Additive Experts. Series of Technical Information, N. 733, Geneva.

Iammarino M, Ientile AR, Di Taranto A. 2017. Sulphur dioxide in meat products: 3-year control results of an accredited Italian laboratory. Food Additives \& Contaminants: Part B. 10:99104.

ISO (1998). ISO 1988-2:1998, Foodstuffs. Determination of sulfite. Enzymatic method, International Organization for Standardization, Geneva, Switzerland.

Mackie A. 2005. Survey of fat content, sulphur dioxide and meat species present in minced meat sold in Scotland during 2000 to 2002. Edinburgh.

Ruiter A, Scherpenisse P. 2011. Analysis of Chemical Preservatives in Foods. In: Methods of Analysis of Food Components and Additives, Second Edition. CRC Press. p. 423-444.

Ruiz-Capillas C, Jiménez-Colmenero F. 2009. Application of flow injection analysis for determining sulphites in food and beverages: A review. Food Chemistry. 112:487-493.

Serbian Veterinary Law, 2005. Official Gazette of the Republic of Serbia Vol.91 No.05.

Serbian Food Safety Law, 2009. Official Gazette of the Republic of Serbia Vol.41 No.09.

Tomasevic I, Kuzmanović J, Andelković A, Saračević M, Stojanović MM, Djekic I. 2016. The effects of mandatory HACCP implementation on microbiological indicators of process hygiene in meat processing and retail establishments in Serbia. Meat Science. 114:54-57.

Tomašević I, Šmigić N, Dekić I, Zarić V, Tomić N, Rajković A. 2013. Serbian meat industry: A survey on food safety management systems implementation. Food Control. 32:25-30.

Tomašević I, Šmigić N, Đekić I, Zarić V, Tomić N, Rajković A. 2013. Serbian meat industry: A survey on food safety management systems implementation. Food Control. 32:25-30.

Vandevijvere S, Temme E, Andjelkovic M, De Wil M, Vinkx C, Goeyens L, Van Loco J. 2010. Estimate of intake of sulfites in the Belgian adult population. Food Additives \& Contaminants: Part A. 27:1072-1083.

Zubeldia Lauzurica L, Gomar Fayos J. 1997. Presence of sulfites in minced meat and meat products prepared in industries of the Valencia Community. Revista espanola de salud publica. 71:401-407. 
Table 1 Sulfite content (mg kg-1) in different categories of meat products over a decade.

\begin{tabular}{|c|c|c|c|c|c|c|c|}
\hline & & $\begin{array}{l}\text { Minced } \\
\text { Pork }\end{array}$ & $\begin{array}{c}\text { Minced } \\
\text { Beef }\end{array}$ & $\begin{array}{c}\text { Ćevapi } \\
\text { (Kebab) }\end{array}$ & $\begin{array}{c}\text { Pljeskavica } \\
\text { (Burger) }\end{array}$ & $\begin{array}{c}\text { Fresh } \\
\text { Sausage }\end{array}$ & Total \\
\hline \multirow{4}{*}{2007} & Number of samples & 33 & 32 & 163 & 61 & 169 & 458 \\
\hline & Non-compliant (\%) & 32.2 & 25 & 26.3 & 19.6 & 20.11 & 23.3 \\
\hline & Range non-compliant & $87-338$ & $38-265$ & $31-373$ & $70-303$ & $20-353$ & $20-373$ \\
\hline & Mean \pm SD & $58.7 \pm 97.6$ & $42.2 \pm 81.2$ & $47.2 \pm 84.3$ & $41.5 \pm 86.0$ & $38.2 \pm 80.5$ & $43.6^{\mathrm{a}} \pm 83.8$ \\
\hline \multirow{4}{*}{2008} & Number of samples & 68 & 92 & 372 & 143 & 382 & 1057 \\
\hline & Non-compliant (\%) & 22 & 14.1 & 25.8 & 23.8 & 11.5 & 19.1 \\
\hline & Range non-compliant & $66-321$ & $66-243$ & $39-368$ & $40-453$ & $41-870$ & $39-870$ \\
\hline & Mean \pm SD & $41.6 \pm 82.6$ & $24.7 \pm 58.9$ & $36.9 \pm 72.7$ & $35.0 \pm 73.3$ & $22.5 \pm 71.1$ & $30.7^{\mathrm{b}, \mathrm{c}, \mathrm{d}} \pm 72.0$ \\
\hline \multirow{4}{*}{2009} & Number of samples & 92 & 68 & 150 & 52 & 121 & 483 \\
\hline & Non-compliant (\%) & 16.3 & 8.8 & 27.3 & 34.6 & 14.9 & 20.3 \\
\hline & Range non-compliant & $62-236$ & $45-418$ & $57-277$ & $79-279$ & $64-255$ & $45-418$ \\
\hline & Mean $\pm \mathrm{SD}$ & $29.1 \pm 65.4$ & $18.2 \pm 64.9$ & $53.3 \pm 86.7$ & $64.5 \pm 92.1$ & $24.0 \pm 55.7$ & $37.6^{\mathrm{a}, \mathrm{b}} \pm 75.2$ \\
\hline \multirow{4}{*}{2010} & Number of samples & 106 & 83 & 193 & 73 & 177 & 632 \\
\hline & Non-compliant (\%) & 11.3 & 9.6 & 31.0 & 19.2 & 12.4 & 18.3 \\
\hline & Range non-compliant & $80-266$ & $94-280$ & $75-341$ & $77-319$ & $15-272$ & $15-41$ \\
\hline & Mean \pm SD & $23.3 \pm 61.4$ & $20.9 \pm 59.7$ & $59.6 \pm 90.6$ & $39.9 \pm 82.8$ & $22.6 \pm 58.1$ & $35.8^{\mathrm{a}, \mathrm{b}, \mathrm{c}}{ }_{ \pm 74.8}$ \\
\hline \multirow{4}{*}{2011} & Number of samples & 62 & 41 & 204 & 68 & 152 & 527 \\
\hline & Non-compliant (\%) & 3.2 & 4.9 & 9.3 & 11.7 & 7.2 & 7.9 \\
\hline & Range non-compliant & $161-199$ & $194-211$ & $11-316$ & $14-274$ & $66-249$ & $14-316$ \\
\hline & Mean \pm SD & $8.4 \pm 31.8$ & $12.4 \pm 43.6$ & $19.8 \pm 58.9$ & $18.3 \pm 52.5$ & $15.33 \pm 47.6$ & $16.42^{\mathrm{e}} \pm 51.2$ \\
\hline \multirow{4}{*}{2012} & Number of samples & 28 & 8 & 319 & 97 & 205 & 657 \\
\hline & Non-compliant (\%) & 10.7 & 0 & 13.5 & 6.2 & 9.8 & 10.9 \\
\hline & Range non-compliant & $27-193$ & 0 & & $12-241$ & $62-260$ & $11-324$ \\
\hline & Mean \pm SD & $15.3 \pm 43.7$ & $3.9 \pm 3.53$ & $27.82 \pm 69.9$ & $11.8 \pm 40.4$ & $18.8 \pm 51.9$ & $21.8^{\mathrm{d}, \mathrm{e}} \pm 59.7$ \\
\hline \multirow{4}{*}{2013} & Number of samples & 56 & 12 & 341 & 131 & 212 & 752 \\
\hline & Non-compliant (\%) & 7.1 & 0 & 10.6 & 6.9 & 3.8 & 7.6 \\
\hline & Range non-compliant & $105-247$ & 0 & $17-391$ & $135-298$ & $81-332$ & $17-391$ \\
\hline & Mean \pm SD & $16.2 \pm 51.4$ & $3.52 \pm 2.88$ & $25.3 \pm 71.7$ & $16.3 \pm 53.1$ & $10.7 \pm 43.4$ & $18.6^{\mathrm{e}} \pm 59.9$ \\
\hline \multirow{4}{*}{2014} & Number of samples & 86 & 38 & 537 & 202 & 227 & 1090 \\
\hline & Non-compliant (\%) & 8.1 & 5.3 & 11.2 & 5.4 & 6.2 & 8.6 \\
\hline & Range non-compliant & $104-241$ & $30-120$ & $48-501$ & $92-344$ & $112-359$ & $30-501$ \\
\hline & Mean \pm SD & $16.7 \pm 49.1$ & $6.5 \pm 19.4$ & $26.9 \pm 74.0$ & $12.5 \pm 45.5$ & $16.8 \pm 58.3$ & $20.6_{ \pm 63.5}^{\mathrm{e}^{\mathrm{e}}}$ \\
\hline \multirow{4}{*}{2015} & Number of samples & 99 & 16 & 334 & 382 & 296 & 1127 \\
\hline & Non-compliant (\%) & 24.2 & 0 & 6.8 & 6.3 & 4.4 & 7.5 \\
\hline & Range non-compliant & $49-217$ & 0 & $52-605$ & $45-381$ & $51-572$ & $45-605$ \\
\hline & Mean $\pm \mathrm{SD}$ & $29.6 \pm 51.4$ & $3.9 \pm 3.4$ & $17.3 \pm 63.0$ & $14.9 \pm 53.0$ & $10.0 \pm 44.8$ & $15.5^{\mathrm{e}} \pm 53.9$ \\
\hline \multirow{4}{*}{2016} & Number of samples & 29 & 7 & 210 & 168 & 154 & 568 \\
\hline & Non-compliant $(\%)$ & 17.3 & 0 & 10.9 & 4.8 & 2.6 & 7.0 \\
\hline & Range non-compliant & $76-479$ & 0 & $82-549$ & $140-463$ & $189-898$ & 76-898 \\
\hline & Mean \pm SD & $49.2 \pm 118.5$ & $4.1 \pm 3.8$ & $35.6 \pm 103.4$ & $17.1 \pm 68.7$ & $12.3 \pm 76.7$ & $24.1^{\mathrm{c}, \mathrm{d}, \mathrm{e}} \pm 88.1$ \\
\hline \multirow{4}{*}{ Total } & Number of samples & 659 & 397 & 2,823 & 1,377 & 2,095 & 7,351 \\
\hline & Non-compliant (\%) & 14.7 & 10.1 & 15.7 & 10.4 & 8.9 & 12.4 \\
\hline & Range non-compliant & $27-479$ & $30-418$ & $11-605$ & $12-463$ & 15-898 & $11-898$ \\
\hline & Mean \pm SD & $26.6^{\mathrm{A}, \mathrm{B}} \pm 64.8$ & $18.9^{\mathrm{B}} \pm 55.6$ & $31.9^{\mathrm{A}} \pm 76.9$ & $21.4^{\mathrm{B}} \pm 62.3$ & $18.7^{\mathrm{B}} \pm 60.4$ & $25.0^{\mathrm{A}, \mathrm{c}, \mathrm{d}, \mathrm{e}} \pm 67.9$ \\
\hline
\end{tabular}

Means not sharing same capital letter in the same row are different significantly at the 0.05 level; Means not sharing same small letter in the same column are different significantly at the 0.05 level. 
Table 2 Sulfite content (mg kg-1) in different categories of meat products before and after mandatory HACCP implementation.

\begin{tabular}{|c|c|c|c|c|c|c|c|c|}
\hline & \multicolumn{4}{|c|}{ Before mandatory HACCP } & \multicolumn{4}{|c|}{ After mandatory HACCP } \\
\hline $\begin{array}{l}\text { Group of } \\
\text { samples }\end{array}$ & $\begin{array}{c}\text { Number } \\
\text { of } \\
\text { samples }\end{array}$ & $\begin{array}{c}\text { Non- } \\
\text { compliant } \\
(\%)\end{array}$ & Mean \pm SD & $\begin{array}{c}\text { Range of } \\
\text { non- } \\
\text { compliant } \\
\text { samples }\end{array}$ & $\begin{array}{c}\text { Number } \\
\text { of } \\
\text { samples }\end{array}$ & $\begin{array}{l}\text { Non- } \\
\text { compliant } \\
(\%)\end{array}$ & Mean \pm SD & $\begin{array}{c}\text { Range of } \\
\text { non- } \\
\text { compliant } \\
\text { samples }\end{array}$ \\
\hline $\begin{array}{l}\text { Minced } \\
\text { pork }\end{array}$ & 344 & 15.7 & $30.2^{\mathrm{A}} \pm 69.7$ & $49-321$ & 315 & 14.4 & & $27-479$ \\
\hline $\begin{array}{c}\text { Minced } \\
\text { beef }\end{array}$ & 307 & 11.7 & $22.4^{\mathrm{A}} \pm 61.3$ & $45-418$ & 90 & 2.5 & $7.1^{\mathrm{B}} \pm 25$ & $29-120$ \\
\hline $\begin{array}{c}\text { Ćevap } \\
\text { (Kebab) }\end{array}$ & 981 & 25.6 & $44.6^{\mathrm{A}} \pm 81.2$ & $39-605$ & 1,842 & & $25.2^{\mathrm{B}} \pm 73.8$ & $11-605$ \\
\hline $\begin{array}{l}\text { Pljeskavica } \\
\text { (Burger) }\end{array}$ & 364 & 21.7 & $38.5^{\mathrm{A}} \pm 78.2$ & $40-453$ & 1,013 & & $15.3^{\mathrm{B}} \pm 54.2$ & $13-463$ \\
\hline $\begin{array}{c}\text { Fresh } \\
\text { Sausage }\end{array}$ & 933 & 13.4 & $25.1^{\mathrm{A}} \pm 67.4$ & $15-870$ & 1,162 & & $13.5^{\mathrm{B}} \pm 53.7$ & $51-898$ \\
\hline Total & 2,929 & 18.6 & $33.6^{\mathrm{A}} \pm 73.8$ & $15-870$ & 4,422 & 8.3 & $19.3^{\mathrm{B}} \pm 63.1$ & 11-898 \\
\hline
\end{tabular}

Means not sharing same capital letter in the same row are different significantly at the 0.05 level.

Table 3 Seasonal variation of sulfite content $(\mathrm{mg} \mathrm{kg}-1)$ in meat products.

\begin{tabular}{cccc}
\hline Season & $\begin{array}{c}\text { Number of } \\
\text { samples }\end{array}$ & $\begin{array}{c}\text { Non-compliant } \\
(\%)\end{array}$ & Mean \pm SD \\
\hline Spring & 2288 & 10.9 & $21.5^{\mathrm{A}} \pm 59.4$ \\
\hline Summer & 1689 & 14.1 & $25.8^{\mathrm{A}, \mathrm{B}} \pm 68.4$ \\
\hline Autumn & 1341 & 10.7 & $24.9^{\mathrm{A}, \mathrm{B}} \pm 74.2$ \\
\hline Winter & 2033 & 13.8 & $30.0^{\mathrm{B}} \pm 76.1$ \\
\hline
\end{tabular}

Means not sharing same capital letter in the same column are different significantly at the 0.05 level. 